\title{
MORPHOLOGICAL, PRODUCTIVE, AND CHEMICAL TRAITS OF XARAÉS GRASS: NITROGEN TOPDRESSING VERSUS INOCULATION WITH DIAZOTROPHIC BACTERIA
}

\section{CARACTERÍSTICAS MORFOLÓGICAS, PRODUTIVAS E BROMATOLÓGICAS DO CAPIM-XARAÉS: ADUBAÇÃO NITROGENADA EM COBERTURA VERSUS INOCULAÇÃO COM BACTÉRIAS DIAZOTRÓFICAS}

\begin{abstract}
Márcio de Souza Dias ${ }^{1}$ ORCID - http://orcid.org/0000-0001-8367-1341 Lucélia Borgo ${ }^{3}$ ORCID - http://orcid.org/0000-0003-3871-2591

1Universidade José do Rosário Vellano, Alfenas, MG, Brazil.

2Centro de Energia Nuclear na Agricultura - USP, Piracicaba, SP, Brazil.

3Faculdade de Americana, Americana, SP, Brazil.

${ }^{*}$ Corresponding author - flaviohsr.agro@yahoo.com.br
\end{abstract} Ligiane Aparecida Florentino' ORCID - http://orcid.org/0000-0001-9092-3017 Flávio Henrique Silveira Rabêlo ${ }^{\star}{ }^{\star}$ ORCID - http://orcid.org/0000-0002-8804-7182 Adauton Vilela de Rezende ${ }^{1}$ ORCID - http://orcid.org/0000-0001-8515-484X Flávia Romam da Costa Souza1 ORCID - http://orcid.org/0000-0003-0482-822X

\begin{abstract}
:
Nitrogen topdressing is essential for forage production, but the high cost of fertilizers stimulates the search for new technologies, such as the use of diazotrophic bacteria, which can fix the atmospheric nitrogen. To evaluate the potential of this technology in providing the amount of nitrogen requested by xaraés grass as topdressing, plants were fertilized at planting with an $\mathrm{N}$ rate of $100 \mathrm{~kg} \mathrm{ha}^{-1}$, inoculated with strains of diazotrophic bacteria and Azospirillum brasilense, and compared with plants that received $100 \mathrm{~kg} \mathrm{ha}^{-1}$ of $\mathrm{N}$ at planting and as topdressing during two periods of shoot growth (58 days in the first period and 26 days in the second period) in $20-\mathrm{dm}^{3}$ pots. The data were subjected to analysis of variance and means compared by the Scott-Knott test at 5\% significance. The leaf area of xaraés grass inoculated with strain UN42 was similar to that of plants that received nitrogen topdressing. However, grass biomass production was higher when nitrogen topdressing was applied. Plant inoculation with Azospirillum brasilense and strains UN16, UN17, UN21, UN33, UN49, and UN78 increased crude protein contents of xaraés grass when compared to nitrogen fertilization at planting without inoculation. However, grass inoculation with diazotrophic bacteria does not replace nitrogen topdressing completely.
\end{abstract}

Keywords: Azospirillum brasilense, biological nitrogen fixation, root system, sustainable production, Urochloa brizantha

\section{Resumo}

A adubação nitrogenada em cobertura é imprescindível para a produção de forragem, mas o elevado custo dos fertilizantes estimula a busca por novas tecnologias, como o uso de bactérias diazotróficas, que podem fixar o nitrogênio atmosférico. Para avaliar o potencial dessa tecnologia em suprir a quantidade de nitrogênio requerida pelo capim-xaraés em cobertura, as plantas foram adubadas em plantio com dose equivalente a $100 \mathrm{~kg} \mathrm{ha}^{-1}$ de $\mathrm{N}$ e inoculadas com estirpes de bactérias diazotróficas e Azospirillum brasilense, e comparadas com plantas que receberam $100 \mathrm{~kg} \mathrm{ha}^{-1}$ de $\mathrm{N}$ em plantio e 
em cobertura, durante dois períodos de crescimento da parte aérea ( 58 dias no primeiro período e 26 dias no segundo período), em vasos de $20 \mathrm{dm}^{3}$. Os dados foram submetidos à análise de variância e as médias comparadas pelo teste Scott-Knott a 5\% de significância. A área foliar do capim-xaraés inoculado com a estirpe UN42 foi semelhante a das plantas que receberam adubação nitrogenada em cobertura. Todavia, a produção de massa do capim foi maior quando houve adubação nitrogenada em cobertura. A inoculação das plantas com Azospirillum brasilense e as estirpes UN16, UN17, UN21, UN33, UN49 e UN78 aumentou os teores de proteína bruta do capim-xaraés em relação à adubação nitrogenada em plantio sem inoculação. Porém, a inoculação do capim com as bactérias diazotróficas não substitui totalmente a adubação nitrogenada em cobertura.

Palavras-chave: Azospirillum brasilense, fixação biológica de nitrogênio, produção sustentável, sistema radicular, Urochloa brizantha

Received on November 20, 2015

Accepted on March 21, 2019.

\section{Introduction}

Brazil has more than 170 million hectares of arable lands occupied by pastures, in which the genus Urochloa (Syn. Brachiaria) stands out for occupying over half of this area ${ }^{(1)}$. However, extensive areas established with Urochloa display some degree of degradation ${ }^{(2)}$. The low natural fertility of soils, associated with a low fertilizer application, is among the main factors that result in the pasture degradation process $^{(3)}$. Thus, fertilization is essential to maintain the productive capacity of pastures, especially nitrogen fertilization ${ }^{(4)}$. Nitrogen is the most limiting element for forage production due to the high quantity required by plants and physiological functions performed by this element ${ }^{(1-3)}$. At first, nitrogen changes some morphological characteristics of pastures, such as leaf size and development and appearance of tillers ${ }^{(5)}$. This nutrient can also improve nutritional traits of forage plants by increasing the crude protein content and decreasing the concentration of structural carbohydrates ${ }^{(6,7)}$.

It is clear that nitrogen fertilization is extremely important in pasture production systems, but the cost of nitrogen fertilizers is high, and their use may result in environmental problems when the management of fertilization is inadequate ${ }^{(4,8)}$. Thus, the adoption of technologies that can contribute to maintaining the productive capacity of forage plants in a more economical manner and with fewer environmental risks should be prioritized $^{(9)}$. In this scenario, the inoculation of pastures with diazotrophic bacteria may be a promising alternative because of the biological nitrogen fixation $(\mathrm{BNF})^{(10)}$. In addition to increasing the uptake of nitrogen, diazotrophic bacteria produce hormones that can alter the morphology of the root system and increase the biomass production of this tissue, thereby increasing soil exploitation capacity ${ }^{(11)}$. However, the association of diazotrophic bacteria may be conditioned to vegetation, and different cultivars of Urochloa may have a selective effect on the bacterial population, resulting in different responses regarding the contribution of BNF in forage $\operatorname{grasses}^{(12)}$.

Most researches on nitrogen-fixing bacteria in forage grasses were conducted between the 60s and 80 s, especially with species of the genus Azospirillum $^{(13)}$. Yet, few studies evaluated the effects of $\mathrm{BNF}$ on the morphological and chemical characteristics of forage grasses, which are known to be significantly modified by nitrogen fertilization ${ }^{(5-7)}$. Therefore, it is necessary to resume the research with BNF in forage grasses, given that new strains of bacteria can be found and their BNF potential can be exploited ${ }^{(9,10,12)}$. Moreover, it is interesting to evaluate the ability of new strains of diazotrophic 
bacteria to provide the amount of nitrogen required by forage grasses throughout their growth (nitrogen topdressing) since positive results could represent significant advances in forage crops. Thus, we aimed to evaluate some morphological, productive, and chemical traits of Urochloa brizantha cv. Xaraés (xaraés grass) inoculated with strains of diazotrophic bacteria and Azospirillum brasilense and determine the potential of this technology to provide the nitrogen required as topdressing by xaraés grass. Our hypothesis is that xaraés grass inoculated with strains of diazotrophic bacteria and Azospirillum brasilense decreases its nutritional requirement by nitrogen due to BNF, decreasing the need for nitrogen at topdressing.

\section{Material and Methods}

The study was carried out from August to December 2014, in Alfenas-MG (21 $25^{\prime} 44^{\prime \prime}$ S and 45 $56^{\prime} 49^{\prime \prime}$ $\mathrm{W})$, which is located in the southeast region of Brazil, at an altitude of $888 \mathrm{~m}$. The regional climate is a tropical mesothermal, according to Köppen classification. Climate conditions recorded during the study are shown in Figure 1. The soil used in this study was classified as an Oxisol, with a clayey texture and the following chemical properties analyzed in the top $0-20 \mathrm{~cm}$ layer ${ }^{(14)}: \mathrm{pH}\left(\mathrm{H}_{2} \mathrm{O}\right)=5.2$; P-Mehlich $=0.5 \mathrm{mg} \mathrm{dm}^{-3} ; \mathrm{K}+=21 \mathrm{mg} \mathrm{dm}^{-3} ; \mathrm{Ca}_{2}+=0.3 \mathrm{cmolc} \mathrm{dm}^{-3} ; \mathrm{Mg}_{2}+=0.2 \mathrm{cmolc} \mathrm{dm}^{-3} ; \mathrm{Al}_{3}+=$ $0.2 \mathrm{cmolc} \mathrm{dm}^{-3} ; \mathrm{H}+\mathrm{Al}=2.6 \mathrm{cmolc} \mathrm{dm}^{-3} ;$ sum of bases $=0.55 \mathrm{cmolc} \mathrm{dm}^{-3} ;$ potential $\mathrm{CEC}=3.15 \mathrm{cmolc}$ $\mathrm{dm}^{-3}$; base saturation $(\mathrm{V} \%)=17.5$; aluminum saturation $(\mathrm{m} \%)=26.5$; and organic matter $(\mathrm{O} . \mathrm{M})=$. $60 \mathrm{~g} \mathrm{~kg}^{-1}$ of soil.

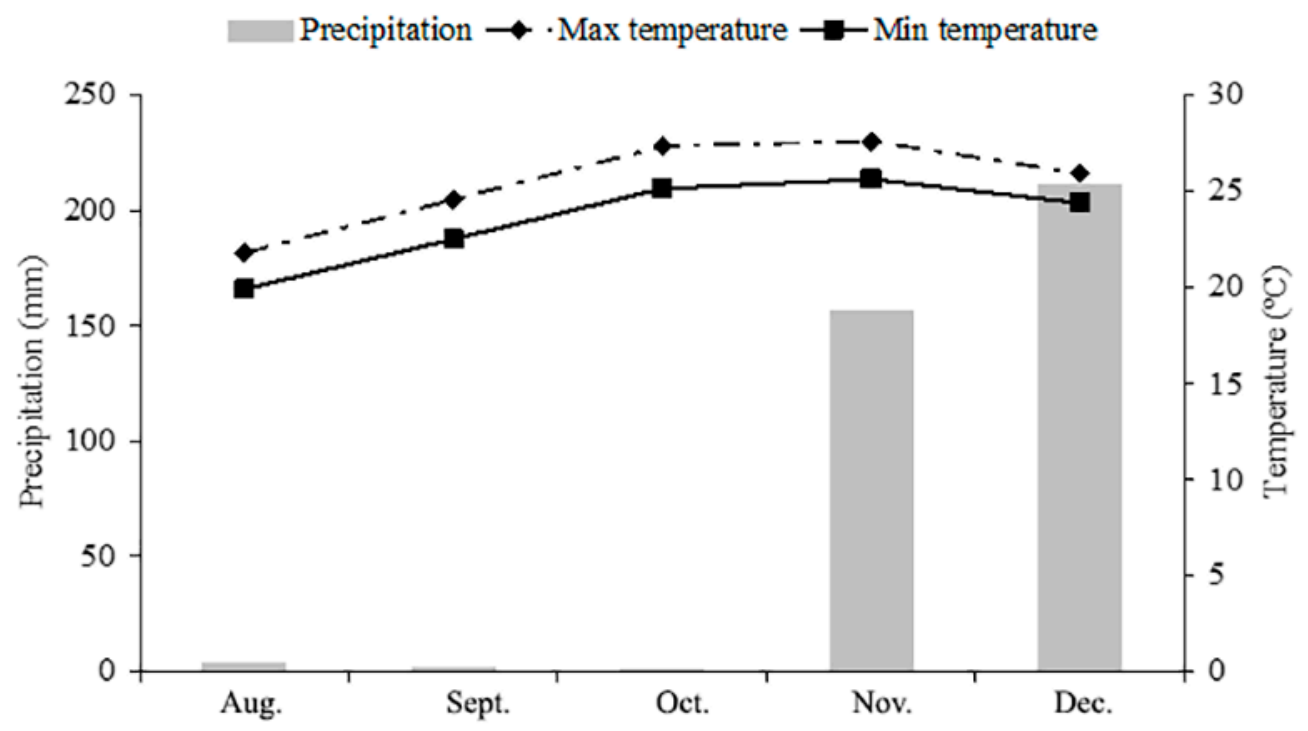

Months - 2014

Figure 1: Average temperatures and accumulated precipitation during the studied period (from soil incubation to the second harvest of the xaraés grass shoots) from the weather station of the Universidade José do Rosário Vellano - UNIFENAS.

The study was conducted in plastic pots with a capacity of $20 \mathrm{dm}^{3}$ of soil, aiming to minimize possible experimental errors. The soil used in the experiment (properties mentioned above) was transferred to pots after its acidity was corrected (dolomitic limestone with $90 \%$ relative TNP to 
increase base saturation to $70 \%$ ) and fertilization was applied at planting, being $90 \mathrm{~kg} \mathrm{ha}^{-1} \mathrm{P}_{2} \mathrm{O}_{5}$ as single superphosphate $\left(18 \% \mathrm{P}_{2} \mathrm{O}_{5}, 16 \% \mathrm{Ca}\right.$, and $\left.8 \% \mathrm{~S}\right)$ and $120 \mathrm{~kg} \mathrm{ha}^{-1} \mathrm{~K}_{2} \mathrm{O}$ as potassium chloride $\left(60 \% \mathrm{~K}_{2} \mathrm{O}\right)$. Subsequently, the soil remained incubated for 40 days, with moisture maintained at $70 \%$ of the field capacity by using distilled water. During the soil incubation period, plantlets of xaraés grass were cultivated for 21 days in Styrofoam trays containing a substrate composed of pine, peat, and vermiculite. After the soil incubation period, six plantlets were transferred to each plastic pot, which marked the beginning of treatments, which consisted of nitrogen fertilization at planting (control treatment); nitrogen fertilization at planting and nitrogen topdressing; nitrogen fertilization at planting and inoculation with Azospirillum brasilense; and nitrogen fertilization at planting and inoculation with new strains of diazotrophic bacteria.

Nitrogen fertilization at planting was applied to all treatments at five days after plantlet transplanting at a rate of $100 \mathrm{~kg} \mathrm{ha}^{-1}$ as urea $(45 \% \mathrm{~N})$. In the treatment that received nitrogen fertilization at planting and topdressing, a rate equivalent to $100 \mathrm{~kg} \mathrm{ha}^{-1}$ was applied as topdressing in the form of urea, split into two applications (20 and 58 days after transferring the plantlets to the pots). In treatments in which plantlets were incubated with Azospirillum brasiliense (Masterfix Gramineas ${ }^{\circledR}$ with strains AbV5 and AbV6 - 2 × $10^{8}$ viable cells per $\mathrm{mL}$ ) and strains of diazotrophic bacteria, the inoculation was performed two days after nitrogen fertilization at planting to prevent possible problems with the establishment of bacteria. Strains used in the inoculation of xaraés grass belong to Universidade José do Rosário Vellano UNIFENAS (UNIFENAS 100-02, UNIFENAS 100-06, UNIFENAS 100-16, UNIFENAS 100-17, UNIFENAS 100-21, UNIFENAS 100-28, UNIFENAS 100-30, UNIFENAS 100-31, UNIFENAS 100-33, UNIFENAS 100-34, UNIFENAS 100-35, UNIFENAS 100-40, UNIFENAS 100-42, UNIFENAS 100-43, UNIFENAS 100-49, UNIFENAS 100-51, UNIFENAS 100-67, UNIFENAS 100-69, UNIFENAS 100-71, UNIFENAS 100-78, UNIFENAS 100-82, and UNIFENAS 100-280). Strains were named, respectively, as UN02, UN06, UN16, UN17, UN21, UN28, UN30, UN31, UN33, UN34, UN35, UN40, UN42, UN43, UN49, UN51, UN67, UN69, UN71, UN78, UN82, and UN280. These strains were selected when they were able to produce the phytohormone indole-3-acetic acid (IAA) in vitro and solubilize phosphate (unpublished data). It should be mentioned that strains of diazotrophic bacteria used to inoculate xaraés grass were isolated from the root system (endophytic) and the soil cultivated with plants of Urochloa brizantha cv. Marandu. Subsequently, the strains of bacteria were cultivated in PDA (potato dextrose agar) medium and incubated for three days under stirring at $28{ }^{\circ} \mathrm{C}$. Plantlet inoculation process was performed with an aliquot of $5 \mathrm{~mL}$ of a suspension of cells containing around $10^{9}$ cells. Plastic pots containing non-inoculated and inoculated xaraés grass plantlets were distributed in random blocks with four replications (four pots per treatment), totaling 25 treatments and 100 experimental units.

During the study, the soil was irrigated periodically with distilled water to keep soil moisture at $70 \%$ of the field capacity. The first harvest of the xaraés grass shoots was made fifty-eight days after the plantlets were transplanted, at $10 \mathrm{~cm}$ above the soil surface, adopting the plant height (40 $\mathrm{cm})$ as the criterion for harvesting. After the first harvest, plants were inoculated again with their respective treatments, according to the procedure described for the first inoculation. The second harvest of the xaraés grass shoots occurred twenty-six days after the first harvest $(10 \mathrm{~cm}$ above soil surface), adopting the same criterion as the first harvest. However, before the harvest was made, width and length of xaraés grass leaves (first fully expanded leaf in the direction from the apex to the plant base) was measured with a graduated ruler, which allowed for the calculation of leaf area (leaf length x width) at each growth period. Subsequently, the calculated leaf area was corrected using the multiplication factor $0.905^{(15)}$. Tillers were counted during harvests for the calculation 
of the tiller appearance rate, which was determined as the quotient between the number of tillers and growth interval at each period (days). After the second harvest was made, the soil adhering to the root system of xaraés grass was separated, and the length of the main root was measured with a graduated ruler. Subsequently, the collected material (shoots from two growth periods and root system) was dried in a forced air ventilation oven at $60{ }^{\circ} \mathrm{C}$ for $72 \mathrm{~h}$. The dry plant material was placed on a precision scale to determine dry matter production, ground in a Wiley mill with 1-mm sieves, and subjected to chemical analyses.

Chemical analyses were performed only in the plant material originating from the second growth of the xaraés grass shoots due to the limitation imposed by the amount of plant material generated in the first growth period. Dry matter (DM) and total nitrogen (TN) contents were determined by methods described by the Association of Official Analytical Chemists ${ }^{(16)}$. Crude protein (CP) content was obtained by multiplying TN content by the factor 6.25. Neutral detergent fiber (NDF) and acid detergent fiber (ADF) contents were determined according to Goering \& Van Soest ${ }^{(17)}$, and hemicellulose content was obtained as the difference between NDF and ADF. The total digestible nutrients (TDN, Eq. 1), digestible energy (DE, Eq. 2), metabolizable energy (ME, Eq. 3), and dry matter digestibility (DMD, Eq. 4) were calculated by equations described by Rodrigues ${ }^{(18)}$ :

$$
\mathrm{TDN}=87.48-(0.7 \mathrm{x} \text { ADF })
$$

where:

TDN - total digestible nutrients (\%)

ADF - acid detergent fiber (\%)

$$
\mathrm{DE}=\mathrm{TDN} \times 0.04409
$$

where:

$\mathrm{DE}$ - digestible energy (Mcal kg-1 DM)

TDN - total digestible nutrients (\%)

$\mathrm{ME}=\mathrm{DE} \times 0.82$

where:

ME - metabolizable energy (Mcal kg-1 DM)

DE - digestible energy (Mcal kg-1 DM)

$\mathrm{DMD}=88.9-(0.779 \times \mathrm{ADF})$

where:

DMD - dry matter digestibility (\%)

ADF - acid detergent fiber (\%)

The data obtained were subjected to the analysis of variance, with means compared by the ScottKnott test at $5 \%$ significance using the Sisvar ${ }^{\circledR}$ statistical program ${ }^{(19)}$. The mathematical model 
used in the analysis of the data is described below:

$Y i j k=\mu+t i+\beta k(j)+\varepsilon i j k$

where: $\mu=$ constant of the experiment; $t i=$ effect of the treatment $i(i=1, \ldots, 25) ; \beta k(j)=$ effect of the block $\mathrm{k}$ within the period $\mathrm{j}(\mathrm{k}=1, \ldots, 4)$; $\varepsilon \mathrm{ijk}=$ effect of the experimental error.

\section{Results and Discussion}

Inoculation of xaraés grass with the diazotrophic bacteria strains UN02, UN21, UN28, UN31, UN33, UN35, UN40, UN42, UN51, and UN71 in the first growth period resulted in higher leaf width values than in plants inoculated with Azospirillum brasilense, but lower values when compared to those of plants that received nitrogen topdressing (Table 1). However, the leaf width of plants inoculated with the strains mentioned above was the same as the results obtained in the treatment with nitrogen topdressing in the second growth period. The highest values of leaf length and leaf area were found when plants received nitrogen topdressing, but plant inoculation with strain UN42 resulted in values close to those observed in this treatment, in both growth periods of the xaraés grass shoots. This fact can be attributed to the higher nitrogen uptake by xaraés grass in these treatments, as this nutrient stimulates the synthesis of enzyme ribulose-1,5bisphosphate carboxylase oxygenase, which is involved in the carbon assimilation and, in turn, results in a higher length and larger leaf area $^{(20-21)}$.

The greatest tillering in xaraés grass was found in the treatment with nitrogen topdressing in both growth periods, which resulted in higher tiller appearance rates when compared to the others (Table 1). It occurs because nitrogen addition increases the capacity of formation of axillary buds, which originate new tillers in forage grasse ${ }^{(5)}$. Biomass production by the xaraés grass shoots was also higher when nitrogen topdressing was applied in both growth periods. Although plant inoculation with bacteria strain UN42 resulted in a larger leaf area than other strains, this fact did not result in higher biomass production. Larger leaf areas are not necessarily associated with higher dry matter yields since the leaf blade thickness may be lower ${ }^{(20)}$.

The greatest lengths and dry matter yields in the roots of xaraés grass occurred when nitrogen topdressing was applied (Table 1). However, it is noteworthy that plant inoculation with nitrogen-fixing bacteria resulted in greater root lengths when compared to those of the control system, especially strains UN06, UN17, UN21, UN40, UN42, and UN78, which provided a higher biomass production when compared to the others. Nitrogen is the nutrient that most influences root development, and when supplied adequately, it allows for the higher accumulation of carbohydrates by the root system, which usually results in greater length and biomass production $^{(22)}$. In addition to increasing nitrogen uptake, diazotrophic bacteria stimulate hormone production, modifying the morphology of the root system and increasing biomass production of this tissue, which results in a higher soil exploitation capacity ${ }^{(11)}$.

It is clear that nitrogen supply is essential for the development of xaraés grass and that plant inoculation with strains of diazotrophic bacteria associated with nitrogen fertilization at planting may result in better morphological and productive traits when compared to inoculation with 
Azospirillum brasilense and nitrogen fertilization at planting without inoculation (Table 1). Nevertheless, it is important that plant inoculation improve chemical traits of xaraés grass to justify the recommendation of this technology. Therefore, it can be observed that DM and NDF contents of xaraés grass (Table 2) inoculated with some strains of diazotrophic bacteria belonging to UNIFENAS were the same as those of plants that received nitrogen topdressing. There was no significant difference $(\mathrm{P}<0.05)$ between ADF, hemicellulose, TDN, DE, and ME contents between plants that received nitrogen topdressing and those inoculated with strains of diazotrophic bacteria and Azospirillum brasilense. The NDF and ADF contents had a direct effect on digestibility and intake of forage by ruminants, being used as forage quality parameters. Concentrations of NDF above 55\% and ADF contents above $40 \%$ result in lower digestibility and intake of forage by ruminants ${ }^{(23)}$. The NDF and ADF contents of xaraés grass found in this study are higher than the range considered limiting to forage intake, in all treatments, which indicates that these contents are more closely related to physiological and structural traits of the forage grass than to the supply of nitrogen ${ }^{(7)}$.

Dry matter digestibility of xaraés grass was not significantly altered $(\mathrm{P}<0.05)$ the treatments (Table 2), which may be attributed to the small variation in NDF and ADF contents ${ }^{(23)}$. Regarding $\mathrm{CP}$ content, the highest value was found with nitrogen topdressing (Table 2). It is extremely desirable for the feeding of ruminants that $\mathrm{CP}$ contents of forage remain above $7 \%$ since values below this threshold lead to lower forage digestion due to inadequate levels of nitrogen, which is limiting to the development of ruminal microorganisms, especially fibrolytic bacteria ${ }^{(23)}$. In this regard, it is important to emphasize that plant inoculation with strains UN16, UN17, UN21, UN33, UN49, and UN78 resulted in CP contents higher than 7\%, and the same result was obtained with inoculation with Azospirillum brasilense. 


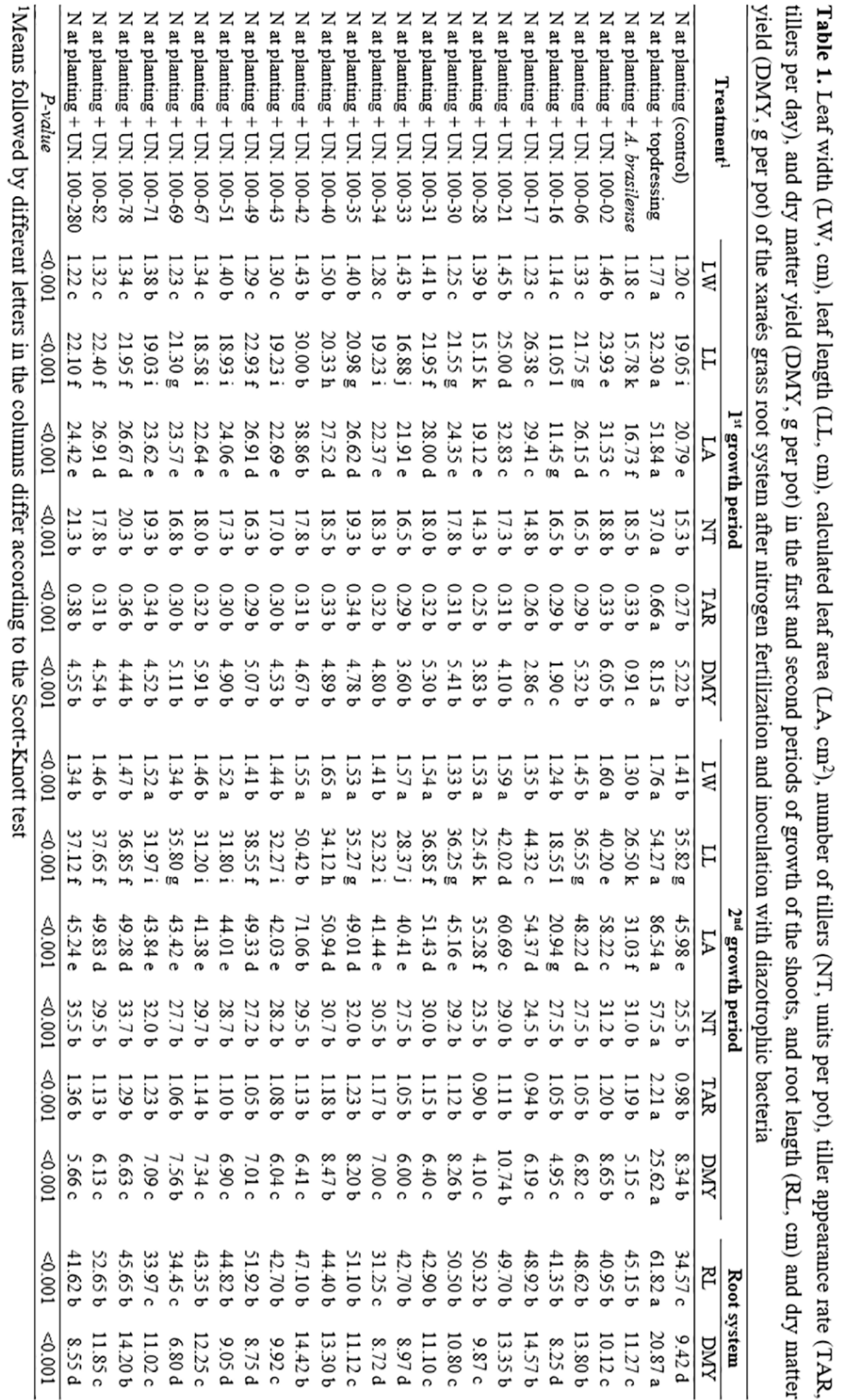




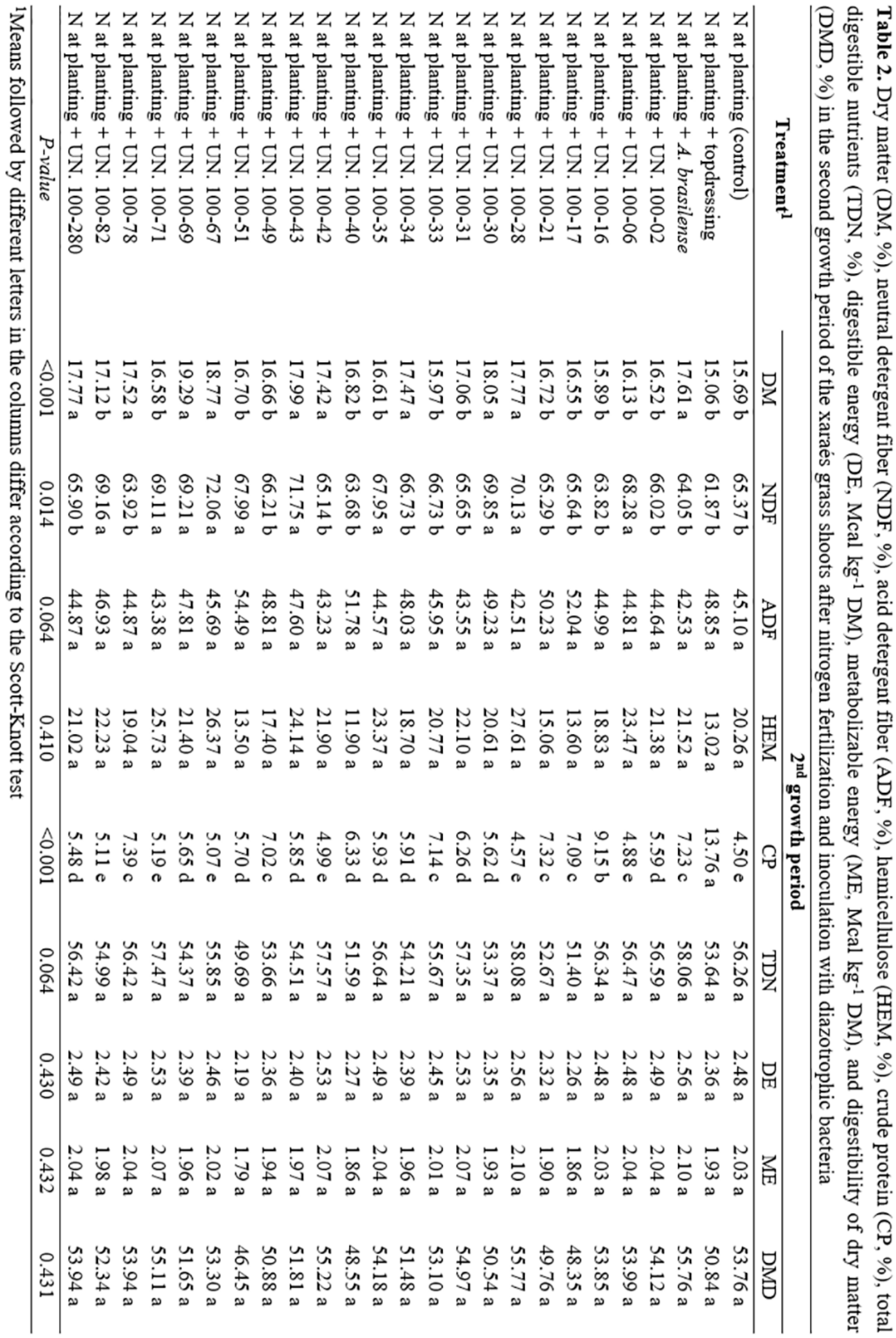




\section{Conclusions}

This study showed that inoculation of xaraés grass with Azospirillum brasilense and some strains of diazotrophic bacteria from UNIFENAS collection increases nitrogen uptake by the forage, but does not replace nitrogen topdressing completely since the dry matter yield of plants inoculated was lower compared to plants that received nitrogen at topdressing.

When no nitrogen topdressing is applied, plant inoculation with diazotrophic bacteria associated with nitrogen fertilization at planting can be a promising alternative when compared to nitrogen fertilization at planting only.

Plant inoculation with bacterial strain UN42 increases leaf area of xaraés grass, but only strains UN02, UN21, UN35, UN40, and UN69 result in a higher biomass production when compared to the control treatment and inoculation with Azospirillum brasilense.

Although inoculation of xaraés grass with strains UN35 and UN69 resulted in a higher biomass production when compared to the control treatment and inoculation with Azospirillum brasilense, chemical properties of the forage inoculated with these strains may limit grazing activity performed by ruminants.

The only strain that resulted in a higher biomass production associated with improvements in the chemical properties was UN21, suggesting that this strain has the potential to be used in the cultivation of xaraés grass.

\section{Acknowledgments}

The authors thank Coordenação de Aperfeiçoamento de Pessoal de Nível Superior - Programa de Suporte à Pós-Graduação de Instituições de Ensino Particulares (CAPES - PROSUP) for the Master's fellowships granted to the first author and the Conselho Nacional de Desenvolvimento Científico e Tecnológico (CNPq) for the "Scientific Initiation" fellowship granted to the fifth author.

\section{References}

1. De Bona FD, Monteiro FA. Marandu palisadegrass growth under nitrogen and sulphur for replacing Signal grass in degraded tropical pasture. Scientia Agrícola. 2010; 67(5):570-578. Available from: http://dx.doi. org/10.1590/S0103-90162010000500011.

2. Bonfim-Silva EM, Monteiro FA. Nitrogênio e enxofre em características produtivas do capim-braquiária proveniente de área de pastagem em degradação. Revista Brasileira de Zootecnia. 2006; 35(4):1289-1297. Available from: http://dx.doi.org/10.1590/S1516-35982006000500006.

3. Bonfim-Silva EM, Monteiro FA. Nitrogênio e enxofre na adubação e em folhas diagnósticas e raízes do capim-braquiária em degradação. Revista Brasileira de Zootecnia. 2010; 39(8):1641-1649. Available from: http://dx.doi.org/10.1590/S1516-35982010000800004.

4. Boddey RM, Macedo R, Tarré RM, Ferreira E, Oliveira OC, Rezende CP, Cantarutti RB, Pereira JM, Alves BJR, Urquiaga S. Nitrogen cycling in Brachiaria pastures: the key to understanding the process of pasture decline. Agriculture, Ecosystems and Environment. 2004; 103(2):389-403. Available from: http://dx.doi. 
org/10.1016/j.agee.2003.12.010.

5. Martuscello JÁ, Silva LP, Cunha DNFV, Batista ACS, Braz TGS, Ferreira PS. Adubação nitrogenada em capim-massai: morfogênese e produção. Ciência Animal Brasileira. 2015; 16(1):1-13. Available from: http:// dx.doi.org/10.1590/1089-68916i118730.

6. Oliveira DA, Bonfim-Silva EM, Silveira CP, Monteiro FA. Valor nutritivo do capim-braquiária no primeiro ano de recuperação com aplicações de nitrogênio e enxofre. Revista Brasileira de Zootecnia. 2010; 39(4):716726. Available from: http://dx.doi.org/10.1590/S1516-35982010000400004.

7. Viana MCM, Freire FM, Ferreira JJ, Macedo GAR, Cantarutti RB, Mascarenhas MHT. Adubação nitrogenada na produção e composição química do capim-braquiária sob pastejo rotacionado. Revista Brasileira de Zootecnia. 2011; 40(7):1497-1503. Available from: http://dx.doi.org/10.1590/S1516-35982011000700014.

8. Silveira ML, Vendramini JMB, Sellers B, Monteiro FA, Artur AG, Dupas E. Bahiagrass response and N loss from selected N fertilizer sources. Grass and Forage Science. 2013; 70(1):154-160. Available from: http:// dx.doi.org/10.1111/gfs.12078.

9. Araujo FF, Guaberto LM, Silva IF. Bioprospecção de rizobactérias promotoras de crescimento em Brachiaria brizantha. Revista Brasileira de Zootecnia. 2012; 41(3):521-527. Available from: http://dx.doi.org/10.1590/ $\underline{\text { S1516-35982012000300007. }}$.

10. Baldani JI, Baldani VLD. History on the biological nitrogen fixation research in graminaceous plants: special emphasis on the Brazilian experience. Anais da Academia Brasileira de Ciências. 2005; 77(3):549-579. Available from: http://dx.doi.org/10.1590/S0001-37652005000300014.

11. Franche C, Lindström K, Elmerich C. Nitrogen-fixing bacteria associated with leguminous and nonleguminous plants. Plant and Soil. 2009; 321(1-2):35-59. Available from: http://dx.doi.org/10.1007/s11104$\underline{008-9833-8 .}$

12. Reis Junior FB, Reis VM, Teixeira KRS. Restrição do 16S-23S DNAr intergênico para avaliação da diversidade de Azospirillum amazonense isolado de Brachiaria spp.. Pesquisa Agropecuária Brasileira. 2006; 41(3):431-438. Available from: http://dx.doi.org/10.1590/S0100-204X2006000300009.

13. Neyra CA, Döbereiner J. Nitrogen fixation in grasses. Advances in Agronomy. 1977; 29:1-38. Available from: http://dx.doi.org/10.1016/S0065-2113(08)60214-X.

14. Silva FC. Manual de análises químicas de solos, plantas e fertilizantes. Brasília: Embrapa Solos, Embrapa Informática Agropecuária, Embrapa Comunicação para Transferência de Tecnologia; 1999. 370p.

15. Kemp CD. Methods of estimating the leaf area of grasses from linear measurements. Annals of Botany. 1960; 24(4):491-499. Available from: http://aob.oxfordjournals.org/content/24/4/491.full.pdf.

16. AOAC - Association of Official Analytical Chemists. Official methods of analysis. 15. ed. Washington: Association of Official Analytical Chemists; 1990. 1117p.

17. Goering HK, Van Soest PJ. Forage fiber analysis (Apparatus, reagents, procedures and some applications). Washington: United States Department of Agriculture; 1970. 20p.

18. Rodrigues RC. Avaliação químico-bromatológica de alimentos produzidos em terras baixas para nutrição animal. Pelotas: Empresa Clima Temperado; 2009. 31p.

19. Ferreira DF. Sisvar: A computer statistical analysis system. Ciência e Agrotecnologia. 2011; 35(6):10391042. Available from: http://dx.doi.org/10.1590/S1413-70542011000600001.

20. Premazzi LM, Monteiro FA, Oliveira RF. Crescimento de folhas do capim-bermuda tifton 85 submetido 
à adubação nitrogenada após o corte. Revista Brasileira de Zootecnia. 2011; 40(3):518-526. Available from: http://dx.doi.org/10.1590/S1516-35982011000300008.

21. Pereira OG, Rovetta R, Ribeiro KG, Santos MER, Fonseca DM, Cecon PR. Crescimento do capim-tifton 85 sob doses de nitrogênio e alturas de corte. Revista Brasileira de Zootecnia. 2012; 41(1):30-35. Available from: http://dx.doi.org/10.1590/S1516-35982012000100005.

22. Silveira CP, Oliveira DA, Bonfim-Silva EM, Monteiro FA. Two years of nitrogen and sulfur fertilizations in a signal grass pasture under degradation: changes in the root system. Revista Brasileira de Zootecnia. 2011; 40(6):1195-1203. Available from: http://dx.doi.org/10.1590/S1516-35982011000600006.

23. Van Soest PJ. Nutritional ecology of the ruminant. 2. ed. Ithaca: Cornell University Press; 1994. 476p. 